\title{
IgG based immunome analyses of breast cancer patients reveal underlying signaling pathways
}

\author{
István Gyurján ${ }^{1}$, Sandra Rosskopf ${ }^{1}$, Johana A. Luna Coronell' ${ }^{1}$, Daniela Muhr ${ }^{2}$, \\ Christian Singer ${ }^{2}$ and Andreas Weinhäuse ${ }^{1}$ \\ ${ }^{1}$ Austrian Institute of Technology AIT, Center for Health \& Environment, Molecular Diagnostics Unit, Vienna, Austria \\ ${ }^{2}$ Department of Obstetrics and Gynecology, Medical University of Vienna, Vienna, Austria \\ Correspondence to: Andreas Weinhäusel, email: andreas.weinhaeusel@ait.ac.at \\ Keywords: protein microarray; immunome; breast cancer; signaling pathways; differentially reactive antigens \\ Received: November 08, $2018 \quad$ Accepted: March 23, $2019 \quad$ Published: May 28, 2019 \\ Copyright: Gyurján et al. This is an open-access article distributed under the terms of the Creative Commons Attribution License \\ 3.0 (CC BY 3.0), which permits unrestricted use, distribution, and reproduction in any medium, provided the original author and \\ source are credited.
}

\section{ABSTRACT}

Background: Breast cancer is the most frequent and one of the most fatal malignancies among women. Within the concept of personalized medicine, molecular characterization of tumors is usually performed by analyzing somatic mutations, RNA gene expression signatures or the proteome by mass-spectrometry. Alternatively, the immunological fingerprint of the patients can be analyzed by protein microarrays, which is able to provide another layer of molecular pathological information without invasive intervention.

Results: We have investigated the immune signature of breast cancer patients and compared them with healthy controls, using protein microarray-based IgG profiling. The identified differentially reactive antigens $(n=517)$ were further evaluated by means of various pathway analysis tools. Our results indicate that the immune signature of breast cancer patients shows a clear distinction from healthy individuals characterized by differentially reactive antigens involved in known disease relevant signaling pathways, such as VEGF, AKT/PI3K/mTOR or C-KIT, which is in close agreement with the findings from RNA-based expression profiles.

Conclusion: Differential antigenic properties between breast cancer patients and healthy individual classes can be defined by serum-IgG profiling on protein microarrays. These immunome profiles provide an additional layer of molecular pathological information, which has the potential to refine and complete the systems biological map of neoplastic disease.

\section{INTRODUCTION}

In recent decades great efforts have been made to reduce the incidences of breast cancer, which increases each year. External and internal risk factors, such as the ever-increasing environmental burden, inadequate lifestyles- or dietary habits, are thought to aggravate the current situation [1] and might eventually lead to somatic changes. With the advent of new diagnostic tools, such as ultrasound, magnetic resonance imaging and mammography screenings mortality rates have been slightly reduced [2]. Nevertheless, the low sensitivity or specificity of such techniques results in detection of breast cancer often at an advanced stage. Hence, there is an important need to develop new tools that would allow for early cancer detection and are less invasive (e.g. avoid unnecessary biopsies, irradiation by mammography). This is especially important when clinicians try to discriminate between malignant breast cancer and benign breast lesions. An ideal solution would be to identify cancer specific biomarkers from body fluids, such as blood, urine or saliva. Genomic and proteomic approaches including altered DNA methylation- or microRNA patterns or specific protein signatures could provide solutions for these requirements. Another option would be to detect tumor-associated antibodies specific to tumor antigens of 
patients, before (through screening regimes) or early at the onset of cancer development [3].

Cancer related antigens were first recognized in the 1950's based on observations from chemically induced carcinomas in mice $[4,5,6]$. Ever since tumorassociated antigens have been reported in a variety of cancer entities, such as breast-, ovarian-, prostate- or colon cancer $[7,8,9]$. The immunogenicity of tumor-associated antigens has been attributed to aberrantly expressed proteins, which could derive from mutations, altered posttranscriptional or translational modifications, abnormal cellular localizations or deregulated apoptotic/necrotic processes $[10,11,12]$. From a diagnostic point of view, only one such an antigen is insufficient to discriminate between cases and controls because of lack of sensitivity and specificity, thus multiple antigens have to be used simultaneously. Distinction has to be made as well when classifying antigens whether those are common among most cancers or specific to only one type. As an example, damage-associated molecular patterns (DAMPs) are frequently associated with cancer, chronic inflammation and necrosis $[13,14,15]$. Therefore molecules, such as HSP90, HMGB1, S100 and mitochondrial DNA are frequently detected in diverse cancer-related diagnostic studies $[16,17,18]$. Finding a tumor specific autoantibody signature is even more complicated since there are large variations between patients in general. Breast cancer is also not an exception and it is largely heterogeneous in terms of structural-, molecular-, genomic-, intratumoraland micro-environmental variations [19]. Inflammatory cells, endothelial cell, pericytes, tumor-associated fibroblasts, cancer cells and constituents of extracellular matrix can all display large diversity of antigens on their surface or upon disintegration. The situation becomes even more complex with cancer progression because of accumulating genetic and epigenetic alternations within cancer cells (e.g. increasing aneuploidy), yielding vast amount of aberrantly expressed proteins. Furthermore, along the course of tumor development/progression the temporal changes of immune competence (i.e. immune evasions) could alter the composition of tumor-associated antibodies.

In this study, we have investigated the circulating antibody (IgG) signature of non-hereditary breast cancer patients and compared them with healthy controls, using protein microarray analyses. The aim of this discoveryphase study was to identify breast cancer-associated antigens in order to use them as a potential tool for diagnostics in the future. We asked whether the circulating IgG antibody repertoire of breast cancer patients could reflect spectra of antigens and the biological phenomena they are involved in. Our results indicate that the immune signatures of breast cancer patients show a clear distinction from healthy individuals characterized by the biological pathways in which the corresponding antigens are participate.

\section{RESULTS}

\section{Differentially reactive antigen data shows similarities with expression profiles of breast cancer}

Seventy-seven IgG samples from non-hereditary breast cancer patients were screened on $16 \mathrm{~K}$ protein microarray and compared with 62 IgG samples from healthy controls. The clinico-pathological data of study samples are shown in Table 1. The list of differentially reactive antigenic proteins consists of 516 entries, where 305 antigens were "upregulated" in cancer and 211 antigens reactivity were decreased (Supplementary Table 1).

Having the analyzed IgG samples from sporadic breast cancer patients we scanned the COSMIC database to find concordance with protein entries associated with somatic alternations in breast cancer. Out of the 516 antigens 34 proteins were found (Supplementary Table 1) amongst the so-called COSMIC-census genes $(n=572$, at the time of the study), which considered the most important cancer genes (proteins) with somatic (or both somatic and germ-line) mutations. Meta-analysis also shows the percentage of breast cancer cases (in COSMIC database; $n=883$ samples) in which the given gene was upor down regulated; or copy number variation was detected $(\mathrm{n}=761$ samples) (Supplementary Table 1$)$.

Furthermore, we have checked the overlap between various differentially expressed gene sets and our dataset using GSEA/MSig database, oncogenic- and immunologic signature option. Among the most significant overlaps we found up-regulated gene sets in MCF-7 breast cancer-, and MCF-10 mammary epithelium cell lines, where CCND1, MAP2K1 or EIF4G genes were over-expressed/ knockdown, respectively (Table 2). Regarding the immunologic signature overlap the most significant gene set was that in which the effects of diabetes were measured on peripheral blood mononuclear cells. According to certain studies there is an association between diabetes and the risk of cancer development and outcome [20, 21].

\section{Inferring signaling pathways from differentially reactive antigens}

Ingenuity Global Canonical Pathways were assessed and the top 15 most significant pathways were plotted with the ratio of enrichment (Figure 1A). Supplementary Table 2A shows Ingenuity Canonical Pathway analyses results, threshold set at $\mathrm{p}<0.05$. The top canonical pathways found are related to various immunologicaland inflammatory processes, and to cancer. The most significant $(\mathrm{p}=4.17 \mathrm{E}-05)$ canonical pathway is the $F c \gamma$ Receptor-mediated phagocytosis by macrophages and monocytes. The major function of these receptors is to bind monomeric or aggregated $\mathrm{IgG}$ molecules, immune 
Table 1: Clinico-pathological features of study samples

\begin{tabular}{|c|c|c|}
\hline Characteristics & $\begin{array}{c}\text { Cancer samples } \\
(n=77)\end{array}$ & $\begin{array}{c}\text { Control samples } \\
(n=62)\end{array}$ \\
\hline Mean age $[$ years $\pm \mathrm{SD}]$ & $54.8 \pm 15.3$ & $76.9 \pm 7.7$ \\
\hline \multicolumn{3}{|l|}{ Tumor grade } \\
\hline G1; G2; G3 & $19 ; 23 ; 33$ & $\mathrm{n} / \mathrm{a}$ \\
\hline $\mathrm{N} / \mathrm{A}$ & 2 & \\
\hline Estrogen receptor positive & 49 & $\mathrm{n} / \mathrm{a}$ \\
\hline $\mathrm{N} / \mathrm{A}$ & 28 & \\
\hline Progesterone receptor positive & 27 & $\mathrm{n} / \mathrm{a}$ \\
\hline $\mathrm{N} / \mathrm{A}$ & 50 & \\
\hline Her2/neu receptor positive & 26 & $\mathrm{n} / \mathrm{a}$ \\
\hline pN stage $^{d}$ & & $\mathrm{n} / \mathrm{a}$ \\
\hline pN0; pN1; pN1a; pN1b & $38 ; 5 ; 7 ; 2$ & \\
\hline pN2; pN2a; pN3; pNX & $1 ; 5 ; 4 ; 9$ & \\
\hline $\mathrm{N} / \mathrm{A}$ & 8 & \\
\hline pT stage $^{d}$ & & $\mathrm{n} / \mathrm{a}$ \\
\hline pT1; pT1a; pT1b; pT1c; pT1mic & $2 ; 5 ; 6 ; 27 ; 3$ & \\
\hline pT2; pTis; pTx & $16 ; 12 ; 1$ & \\
\hline $\mathrm{N} / \mathrm{A}$ & 5 & \\
\hline Metastasis stage ${ }^{\mathrm{e}}$ & & $\mathrm{n} / \mathrm{a}$ \\
\hline M0; M1; MX & $19 ; 7 ; 6$ & \\
\hline $\mathrm{N} / \mathrm{A}$ & 45 & \\
\hline \multicolumn{3}{|l|}{ Menopause status ${ }^{\mathrm{f}}$} \\
\hline Pre-menopause & 23 & \\
\hline Post-menopause & 47 & 62 \\
\hline $\mathrm{N} / \mathrm{A}$ & 7 & \\
\hline Chemotherapy before sampling & 2 & $\mathrm{n} / \mathrm{a}$ \\
\hline
\end{tabular}

Abbreviations: $\mathrm{n} / \mathrm{a}$ - not applicable or not available; ${ }^{\mathrm{d}} \mathrm{pT}$ stage and $\mathrm{pN}$ stage information from 71 patients: $\mathrm{pT} 1 \mathrm{a}$ - Tumor less than $0.5 \mathrm{~cm}$ in greatest dimension; pT1b - Tumor more than $1.0 \mathrm{~cm}$ but not more than $1.0 \mathrm{~cm}$ in greatest dimension; pT1c - Tumor more than $1.0 \mathrm{~cm}$ but not more than $2.0 \mathrm{~cm}$ in greatest dimension; pT1mic - Microinvasion $0.1 \mathrm{~cm}$ or less in greatest dimension; pT2 - Tumor more than $2.0 \mathrm{~cm}$ but not more than $5.0 \mathrm{~cm}$ in greatest dimension; pTis - Carcinoma in situ; pN0 - No regional lymph node metastasis; pN1 - Metastasis to movable ipsilateral axillary lymph node(s); pN1a Only micrometastasis (none larger than $0.2 \mathrm{~cm}$ ); pN2 - Metastasis to ipsilateral axillary lymph node(s) fixed to each other or to other structures; $\mathrm{pN} 2 \mathrm{a}$ - Metastasis in 4-9 axillary lymph nodes, including at least one that is larger than 2 mm; pN3 Metastasis to ipsilateral internal mammary lymph node(s); pNX - Axillary lymph nodes cannot be assessed; M0 - No distant metastasis; M1 - Distant metastasis present (includes metastasis to ipsilateral supraclavicular lymph nodes); MX - Presence of distant metastasis cannot be assessed.

complexes or opsonized particles [22]. Upon receptor binding internalization of the complex is initiated with cup formation and subsequent phagosome development, which may finally lead to antigen presentation via activating or inhibitory pathways. These antigens could derive from the cellular constituents of dying macrophages, which are recruited to the sites of tumor, through various "danger signals" (e.g. HSP90 and HMGB2; upregulated in cancer in this dataset; Supplementary Table 1) [13] derived from the tumor itself. High numbers of 
Table 2: Overlap of genes (proteins) from breast cancer vs. control comparison with gene sets from the Molecular Signature Database (MSigDB) within Gene Set Enrichment Analysis (GSEA) tool

\begin{tabular}{|c|c|c|c|}
\hline \multicolumn{4}{|l|}{ A: Oncogenic signature overlaps } \\
\hline Description & $\begin{array}{l}\text { Genes in overlap/ } \\
\text { Genes in genset }\end{array}$ & p-value & $\begin{array}{c}\text { FDR } \\
\text { q-value }\end{array}$ \\
\hline $\begin{array}{l}\text { Genes up-regulated in MCF10 (mammary) cells vs. knockdown of } \\
\text { EIF4G1 gene by RNAi. }\end{array}$ & $10 / 95$ & $1.03 \mathrm{E}-07$ & $1.40 \mathrm{E}-05$ \\
\hline $\begin{array}{l}\text { Genes up-regulated in MCF-7 cells (breast cancer) over-expressing } \\
\text { CCND1 gene. }\end{array}$ & $13 / 188$ & $1.97 \mathrm{E}-07$ & $1.40 \mathrm{E}-05$ \\
\hline $\begin{array}{l}\text { Genes up-regulated in MCF-7 cells (breast cancer) over-expressing a } \\
\text { mutant K112E form of CCND1 gene. }\end{array}$ & $13 / 190$ & $2.22 \mathrm{E}-07$ & $1.40 \mathrm{E}-05$ \\
\hline $\begin{array}{l}\text { Genes up-regulated in SH-SY5Y cells (neuroblastoma) in response to } \\
\text { PDGF stimulation. }\end{array}$ & $11 / 146$ & 7.31E-07 & $3.45 \mathrm{E}-05$ \\
\hline $\begin{array}{l}\text { Genes up-regulated in MCF-7 cells (breast cancer) positive for ESR1. } \\
\text { MCF-7 cells stably over-expressing constitutively active MAP2K1 } \\
\text { gene. }\end{array}$ & $12 / 196$ & $2.09 \mathrm{E}-06$ & 7.90E-05 \\
\hline $\begin{array}{l}\text { Genes up-regulated in granule cell neuron precursors (GCNPs) after } \\
\text { stimulation with Shh for } 24 \mathrm{~h} \text {. }\end{array}$ & $11 / 183$ & $6.60 \mathrm{E}-06$ & $2.08 \mathrm{E}-04$ \\
\hline $\begin{array}{l}\text { Genes up-regulated in epithelial lung cancer cell line over-expressing } \\
\text { an oncogenic form of KRAS gene. }\end{array}$ & $11 / 193$ & $1.09 \mathrm{E}-05$ & 2.72E-04 \\
\hline $\begin{array}{l}\text { Genes down-regulated in primary keratinocytes from RB1 skin } \\
\text { specific knockout mice. }\end{array}$ & $9 / 126$ & $1.15 \mathrm{E}-05$ & $2.72 \mathrm{E}-04$ \\
\hline $\begin{array}{l}\text { Genes down-regulated in HUVEC cells (endothelium) by treatment } \\
\text { with VEGFA. }\end{array}$ & $10 / 193$ & $6.12 \mathrm{E}-05$ & $1.21 \mathrm{E}-03$ \\
\hline Genes up-regulated in NCI-60 panel of cell lines with mutated TP53 & $10 / 194$ & $6.39 \mathrm{E}-05$ & $1.21 \mathrm{E}-03$ \\
\hline \multicolumn{4}{|l|}{ B: Immunologic signature overlaps } \\
\hline $\begin{array}{l}\text { Genes up-regulated in comparison of peripheral blood mononuclear } \\
\text { cells from patients with type } 1 \text { diabetes at the time of diagnosis vs. } \\
\text { those at } 4 \text { month later. }\end{array}$ & $21 / 200$ & $1.08 \mathrm{E}-14$ & $1.03 \mathrm{E}-11$ \\
\hline $\begin{array}{l}\text { Genes up-regulated in peripheral blood mononuclear cells from } \\
\text { patients with type } 1 \text { diabetes at the time of diagnosis vs. those with } \\
\text { type } 2 \text { diabetes at the time of diagnosis. }\end{array}$ & $21 / 200$ & $1.08 \mathrm{E}-14$ & $1.03 \mathrm{E}-11$ \\
\hline $\begin{array}{l}\text { Genes up-regulated in comparison of unstimulated CD8 T cells at } 48 \mathrm{~h} \\
\text { vs. CD } 8 \text { cells at } 48 \mathrm{~h} \text { after stimulation with IL12. }\end{array}$ & $20 / 200$ & $1.18 \mathrm{E}-13$ & 7.54E-11 \\
\hline $\begin{array}{l}\text { Genes up-regulated in comparison of control thymocytes vs. } \\
\text { thymocytes treated with dexamethasone [PubChem=5743]. }\end{array}$ & $19 / 200$ & $1.23 \mathrm{E}-12$ & $5.85 \mathrm{E}-10$ \\
\hline $\begin{array}{l}\text { Genes down-regulated in comparison of unstimulated NK cells vs. } \\
\text { those stimulated with IL2. }\end{array}$ & $18 / 200$ & $1.20 \mathrm{E}-11$ & $1.50 \mathrm{E}-08$ \\
\hline $\begin{array}{l}\text { Genes down-regulated in comparison of } \operatorname{IgD}^{+} \text {peripherial blood B cells } \\
\text { vs. dark zone germinal center B cells. }\end{array}$ & $17 / 200$ & $1.10 \mathrm{E}-10$ & $1.50 \mathrm{E}-08$ \\
\hline $\begin{array}{l}\text { Genes up-regulated in comparison of unstimulated peripheral blood } \\
\text { mononuclear cells vs. those stimulated with YF17D vaccine. }\end{array}$ & $17 / 200$ & $1.10 \mathrm{E}-10$ & $1.50 \mathrm{E}-08$ \\
\hline $\begin{array}{l}\text { Genes down-regulated in comparison of CD8 T cells at } 0 \mathrm{~h} \text { vs. those at } \\
48 \mathrm{~h} \text {. }\end{array}$ & $17 / 200$ & $1.10 \mathrm{E}-10$ & $1.50 \mathrm{E}-08$ \\
\hline $\begin{array}{l}\text { Genes up-regulated in comparison of NKT cells vs. monocyte } \\
\text { macrophages. }\end{array}$ & $17 / 200$ & $1.10 \mathrm{E}-10$ & $1.50 \mathrm{E}-08$ \\
\hline $\begin{array}{l}\text { Genes up-regulated in comparison of CD4 dendritic cells vs. CD4-, } \\
\text { CD8- dendritic cells. }\end{array}$ & $17 / 200$ & $1.10 \mathrm{E}-10$ & $1.50 \mathrm{E}-08$ \\
\hline
\end{tabular}


resident or recruited macrophages at tumor sites are associated with elevated inflammation and poor outcome. Specifically, the found proteins are associated with actin cytoskeleton characteristic to phagocytosis. Tumorassociated macrophage functions are also related to VEGF - $(\mathrm{p}=1.02 \mathrm{E}-03), P T E N-(\mathrm{p}=6.61 \mathrm{E}-03)$ and $m T O R-$ $(\mathrm{p}=2.14 \mathrm{E}-02)$ signaling pathways, which are common examples for cancer related processes including tumor angiogenesis. In summary, most of the found Ingenuity canonical pathways are associated with the components of the PI3K/PTEN/Akt/mTOR pathway, which signaling cascade is estimated to be deregulated by gene mutations in more than $70 \%$ of all breast cancer [23]. Yet worth to mention, the canonical pathway CTLA-4 Signaling in Cytotoxic T Lymphocytes is also highly significant ( $\mathrm{p}=$ 5.75E-04) through Ingenuity. Although the CTLA-4 (Cytotoxic T lymphocyte-associated antigen-4) protein itself is not among the differentially reactive antigens in our dataset the corresponding pathway serves as a good example on how an immune process counteracts with cancer [24]. Of note, another immune-checkpoint molecule LAG-3 (Lymphocyte activation gene-3) is found to be differentially antigenic and upregulated in the cancer group.

Complementing the above results from other aspects we have analyzed our dataset by Pathway Commons as well, using Webgestalt integrated gene-set enrichment tool kit. Figure 1B shows the top 10 identified pathways in PathwayCommons analyses (Supplementary Table 2B). The highest numbers of antigens, 77 proteins, was associated with Betal integrin cell surface interactions $(\mathrm{p}=0.0018)$. In the context of mammary gland development Beta1integrins are essential for luminal polarity and myoepithelial contraction $[25,26]$. Consequently, deregulated expression of integrins results in altered tissue architecture and metastasis of breast cancer $[27,28,29]$. In order to validate and visualize molecular associations (within this category) we have ran protein-protein interaction analysis (String Database). The 77 mapped proteins are predicted to interact with each other with high significance giving 178 observed interactions ( $p=6,11 \mathrm{E}-15)$ (Figure $2 \mathrm{~A})$. One of the central nodes is AKT1 with TSC2 and RAF1 axis; the other core is LCK (lymphocyte-specific protein-tyrosine kinase) with STAT signaling. LCK is a non-receptor protein-tyrosine kinase and has a fundamental role in T-cell receptor mediated signaling, thus thymocyte development and T-cell activation [30].

Yet another highly represented (75 proteins) pathway is the LKB1 mediated signaling ( $\mathrm{p}=0,0021)$ (Figure 1B). The Liver Kinase B1 (LKB1) gene product is a serine/ threonine kinase and has pleiotropic functions in cell growth, epithelial polarity and energy metabolism [31]. LKB1 is also considered as tumor suppressor that is lost in several cancer types [32] including breast cancer [33], and it is able to act through several signaling cascades, such as mTOR, AMPK (5' adenosine monophosphateactivated protein kinase) or PI3K/AKT [34]. Analyzing the molecular associations (String database), composition of the involved molecules in the core part of this network is very similar to the integrin signaling associated molecules mentioned above (only 6 molecules are different), resulting in a slightly higher number of interacting proteins $(n=181, p=1.55 E-15)$ (Figure 2B, Supplementary Table 2B). One unique protein within LKB1 pathway is Ezrin (EZR), which has been shown to mediate breast cancer cell migration, hence facilitating metastasis [35].
A

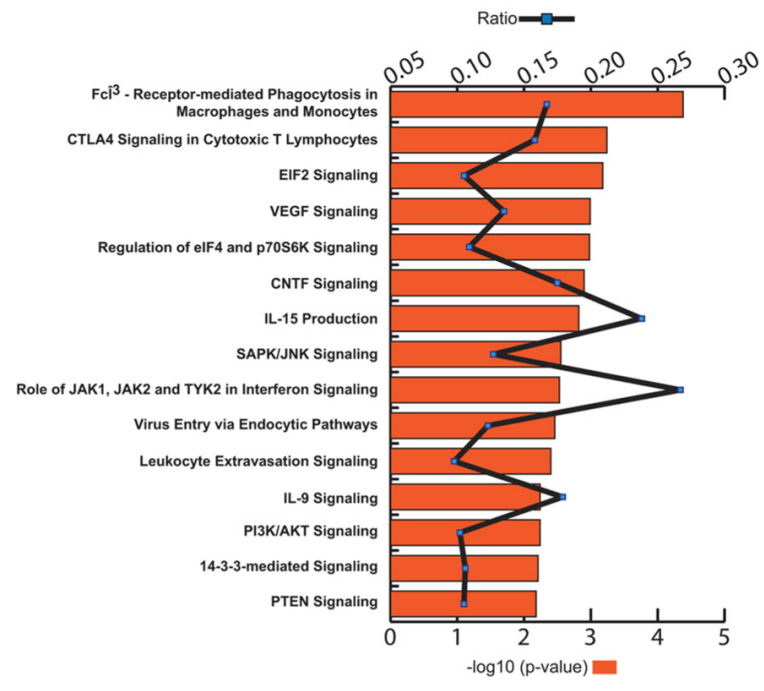

B

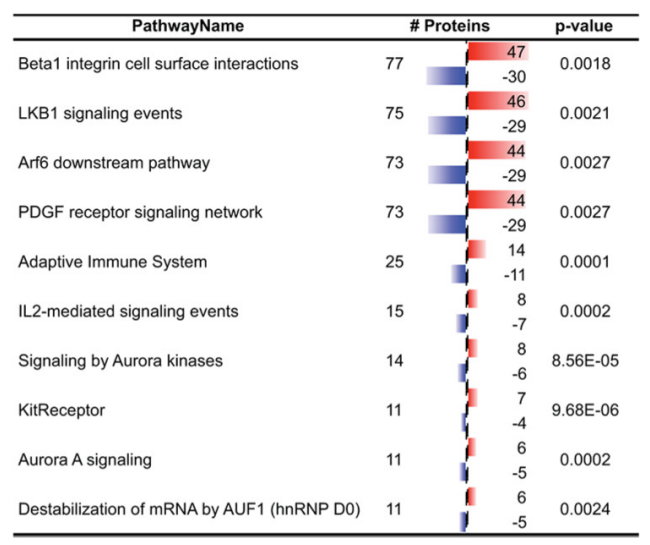

Figure 1: (A) Ingenuity global canonical pathways inferred from differentially reactive antigens. Minus-log10 p-values (bars) and enrichment ratios (line) are shown. (B) Deduced molecular pathways using PathwayCommons tool. Red bar indicates increased-, blue bar decreased antigen binding reactivity. 
Regarding both Beta1-integrin mediated interactions and LKB1mediated signaling in breast cancer the CYLD (cylindromatosis) protein is of paramount importance too, which act as a deubiquitinating enzyme and is considered as a tumor suppressor [36, 37].

In the PathwayCommons analysis the signaling pathway with the highest significance $(p=9.68 \mathrm{E}-06)$ was the Kit-receptor mediated signaling. One of the interesting upregulated protein within this pathway is CISH (CytokinInducible SH2-Containing Protein), which have been found as a key suppressor of IL15 and JAK signaling [38].

The KEGG pathway analyses (Figure 3A; $\mathrm{p}<0,0025)$ resulted in a similar profile of functions to that of Ingenuity, i.e. enrichment of proteins involved in cytoskeletal rearrangements during phagocytosis, VEGFand proteasome pathways and immune cell functions. One of the exceptions from the similarities would be the RNA transport associated event. Molecules within these functions are involved in cytoplasmic transport of RNA, ribosomal binding of RNAs, pre-mRNA splicing, nucleopore complex formation and translation initiation and elongation. The KEGG analysis found 17 RNA transport associated molecules (Supplementary Table 2C) and 27 interactions were predicted by String with high significance $(\mathrm{p}=8.88 \mathrm{e}-16$, Supplementary Figure 1).

The top 20 terms of Reactome analysis $(p \leq 2.12 \mathrm{E}-04$; FDR $\leq 0,012$; Supplementary Table 2D) reinforce some of the findings by Ingenuity, Pathway Commons or KEGG analysis: VEGF-, Kit-, TCR- and MAPK signaling (Figure $3 \mathrm{~B}$ ). The top ranked term "Regulation of $m R N A$ stability by proteins that binds AU-rich element" (p-value=1,7E-7; FDR=2,05E-4) shows also consensus with the PathwayCommons result ("Destabilization of

A

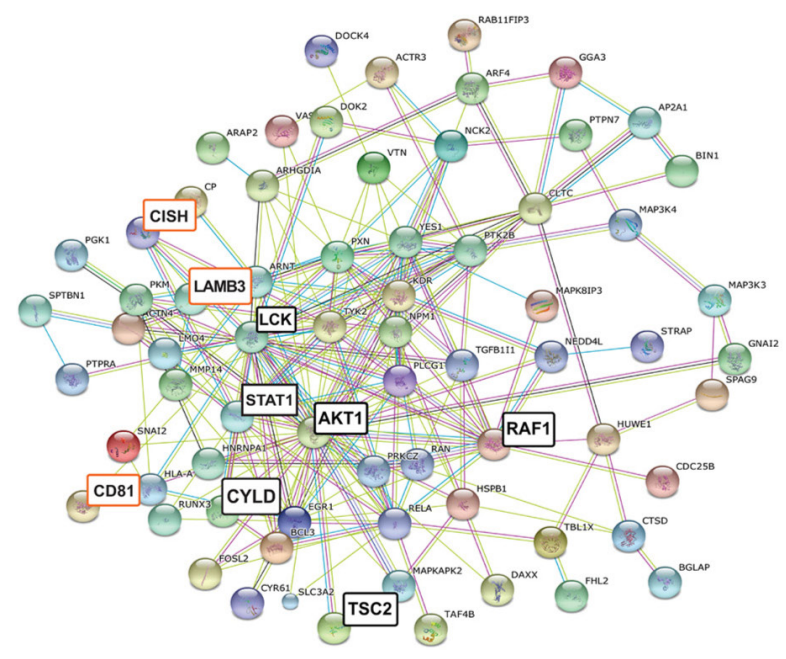

mRNA by AUF1 (hnRNP D0)"). In this process AU rich binding protein (AUF1) dimers bind to adenyl-uridylrich elements (ARE) elements of certain mRNAs` UTR, recruiting additional proteins, such as Poly-A binding protein, heat-shock proteins, translation initiation factor eIF4G, which finally may lead to mRNA degradation [39].

Another important category regarding breast cancer is "Transcriptional regulation by the AP-2 (TFAP2) family of transcription factors". The family members of AP-2 regulate the cell growth and differentiation of tissues of ectodermal origin and involved in the regulation c-erbB-2 (HER2) in breast cancer [40, 41].

We also wanted to find enriched protein domains that are preferentially recognized by the $\operatorname{IgG}$ pool of breast cancer patients. Therefore, InterPro functional classification was performed using all proteins (Cancer vs. Ctrl) with changed immune-reactivity (Figure 4). Ninety-eight proteins showed significantly enriched protein domains $(p<0.05)$. We found that the protein domain with the highest relevance $(p=6.40 \mathrm{E}-04)$ was Immunoglobulin E-set domain, and the most abundant domains were $P$-loop containing nucleoside triphosphate hydrolase $(\mathrm{n}=19 ; \mathrm{p}=2.19 \mathrm{E}-2)$ and $R N A$ recognition motif domain $(\mathrm{n}=12 ; \mathrm{p}=1.45 \mathrm{E}-2)$. Importantly, Protein kinaselike domains, which also include the protein kinase domain subgroup, are also enriched $(p=1.82 \mathrm{E}-02)$ in our dataset. Proteins with these domains are highly conserved and have fundamental role in cell proliferation, apoptosis and differentiation [42].

Finally, we analyzed whether the protein data set was enriched at certain chromosomal locations, i.e. to find possible foci that could be mutational hotspots/targeted by overexpressed or mutated proteins. According to GSEA

B

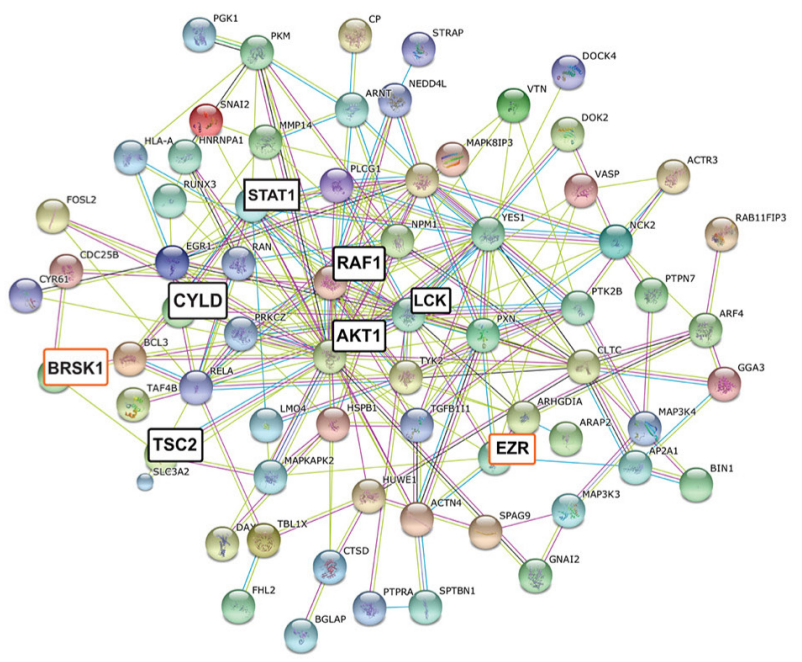

Figure 2: (A) Deduced molecular associations related to integrin-mediated interactions, based on PathwayCommons analysis. (B) Deduced molecular associations related to LKB1-mediated interactions. Disconnected nodes are not shown. Major core molecules are highlighted with black; differences between integrin- and LKB-1 related networks (B) are highlighted with orange. 
(Gene Set Enrichment Analysis) we have found 4 enriched genomic regions: Chr3p21 (14 genes, $\mathrm{p}=2.36 \mathrm{E}-06)$; Chr19q13 (27 genes, p=9.21E-06); Chr19p13 (20 genes, $\mathrm{p}=4.15 \mathrm{E}-05)$ and Chr1p36 (15 genes, $\mathrm{p}=5.63 \mathrm{E}-04)$. (Figure 5A; Supplementary Table 3).

In summary, 502 of 516 differentially reactive protein entries were mapped using String database. These proteins are predicted to be involved in 1968 interactions with each other $(p=9.77 \mathrm{E}-14)$ (Figure 5B). It also suggests that the differentially reactive antigenic protein based immune profiles of breast cancer patients are able to elucidate protein associations/complexes too, and could directly reflect the underlying signaling pathways accompanied with breast cancer development.

\section{DISCUSSION}

In this discovery study, we have used highthroughput protein microarray to identify altered immunereactivity based on breast cancer patients' IgG profile. Recognizing immune-phenotypes by different patient groups not only helps to develop tools for early-stage breast cancer detection, but also allow to get insight into molecular pathways and to devise potential new targets.

Breast cancer, as other tumor types, is not only heterogeneous by means of patients but also consists of different cell types in the tumor microenvironment. Inflammatory cells, endothelial cell, pericytes, tumorassociated fibroblasts, cancer cells and constituents of extracellular matrix can all display large diversity of antigens on their cell-surface or upon disintegration.
The situation becomes even more complex with cancer progression because of accumulating genetic and epigenetic alternations within cancer cells (e.g. increasing aneuploidy), yielding vast amount of aberrantly expressed proteins. Providing that the immune system can recognize these tumor-associated antigens as "non-self", elimination of cancer cells may occur by cytotoxic T-lymphocytes and natural killer cells, as the best scenario. Unfortunately, through the so-called immune editing mechanism [43], cancer cells are capable of escaping from detection and destruction. Looking at the comparison of $\mathrm{IgG}$ profile between the cancer and control group, we could see signs of both escape and elimination events. Related to this the CTLA-4 mediated signaling in CTLs refers to the negative regulation of T-cell function [24], which is clearly unfavorable in the case of cancer. Known as the earliest identified immune-checkpoint molecule, blocking CTLA-4 binding to its ligand with monoclonal antibodies has been recently approved by FDA in melanoma therapy [44]. Similarly to CTLA-4, LAG-3 also belongs to the immunoglobulin superfamily and negatively regulates $\mathrm{T}$ cell function. Since the administration of anti-LAG-3 antibodies were shown to inhibit Treg mediated immune suppression $[45,46]$ LAG-3 has become an attractive new target for immune-therapy.

Analyses revealed differentially reactive proteins involved in tumor angiogenesis (i.e. VEGF) as well, which is considered as an important hallmark of cancer [35]. Both tumor cells and immune-inflammatory cells (e.g. macrophages) are capable to emit vascular endothelial growth factor that can induce tumor-promoting
A

\begin{tabular}{|c|c|c|c|}
\hline Term & & Number of proteins & p-value \\
\hline RNA transport & 17 & & $\begin{array}{c}5 \\
.12 \\
2.97 \mathrm{E}-08\end{array}$ \\
\hline VEGF signaling pathway & 10 & & ${ }_{-6}^{4} 5.54 \mathrm{E}-06$ \\
\hline Proteasome & 7 & & $\begin{array}{r}5 \\
-2 \\
4.21 \mathrm{E}-05\end{array}$ \\
\hline Osteoclast differentiation & 11 & & $\begin{array}{l}6 \\
-5 \\
8.50 \mathrm{E}-05\end{array}$ \\
\hline Amoebiasis & 10 & & $\begin{array}{c}7 \\
-3\end{array}$ \\
\hline Focal adhesion & 14 & & $\begin{array}{l}8 \\
-6 \\
-6\end{array} 1.36 \mathrm{E}-04$ \\
\hline Leukocyte transendothelial migration & 10 & & $\begin{array}{rl}5 & 51.91 \mathrm{E}-04 \\
-5 & \end{array}$ \\
\hline Endocytosis & 13 & & $\begin{array}{l}7 \\
-6 \\
-6\end{array} 4.13 \mathrm{E}-04$ \\
\hline Spliceosome & 10 & & $\begin{array}{l}6 \\
-4.68 \mathrm{E}-04\end{array}$ \\
\hline Progesterone-mediated oocyte maturation & 8 & & $\begin{array}{l}3 \\
-5 \\
4.84 \mathrm{E}-04\end{array}$ \\
\hline Pancreatic cancer & 7 & & $\begin{array}{l}2 \\
-5 \\
5.43 E-04\end{array}$ \\
\hline T cell receptor signaling pattway & 9 & & ${ }_{-3}^{6} 5.72 \mathrm{E}-04$ \\
\hline Chemokine signaling pathway & 12 & & $\begin{array}{l}{ }_{-8}^{4} 8.22 \mathrm{E}-04 \\
\end{array}$ \\
\hline MAPK signaling pathway & 15 & & $\begin{array}{l}78 \\
-8.84 E-04\end{array}$ \\
\hline Fc gamma R-mediated phagocytosis & 8 & & $\begin{array}{l}-49.03 \mathrm{E}-04 \\
-4\end{array}$ \\
\hline B cell receptor signaling pathway & 7 & & $\begin{array}{l}3 \\
-4 \\
1.11 E-03\end{array}$ \\
\hline Acute myeloid leukemia & 6 & 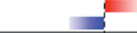 & $\begin{array}{ll}3 & 3.37 \mathrm{E}-03 \\
-3 & \end{array}$ \\
\hline Fc epsilon RI signaling pathway & 7 & & $\begin{array}{l}3.4 \\
-4.41 \mathrm{E}-03\end{array}$ \\
\hline Neurotrophin signaling pathway & 9 & - & $\begin{array}{l}4 \\
-5\end{array}$ \\
\hline Natural killer cell mediated cytotoxicity & 9 & & $\begin{array}{l}{ }_{-5}^{4} 2.32 \mathrm{E}-03 \\
\end{array}$ \\
\hline
\end{tabular}

B

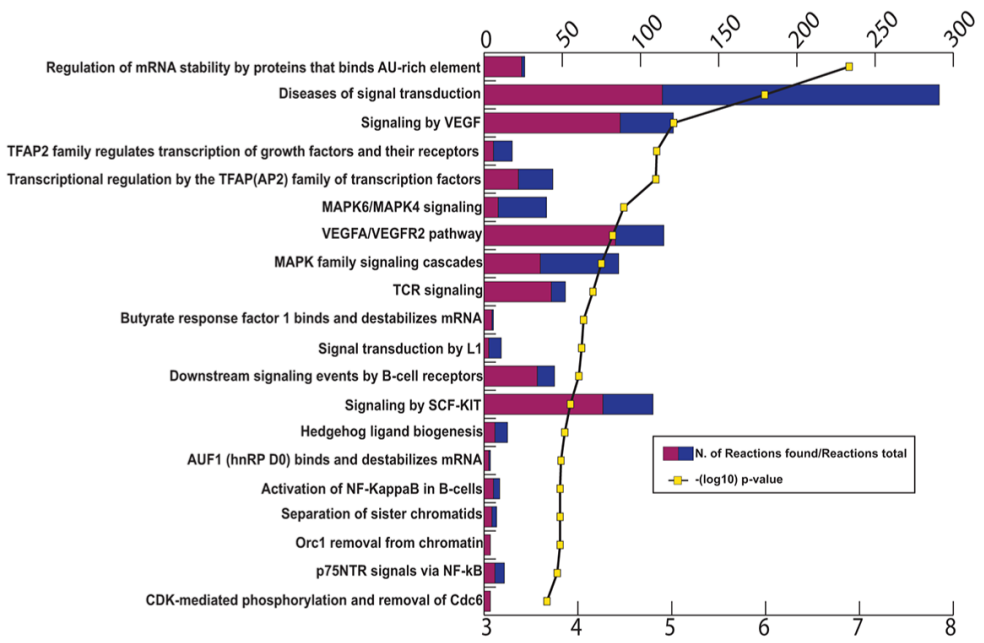

Figure 3: (A) KEGG pathway analysis of differentially antigenic proteins. Red bar indicates increased-, blue bar decreased antigen binding reactivity. (B) REACTOME pathway analysis of differentially antigenic proteins. Purple/blue bars represent the number of related reactions/all reactions in category; yellow line shows - $(\log 10)$ p-values. 
angiogenesis. Moreover, matrix-bound latent VEGF ligand can be released by proteases responsible for degrading extracellular matrix [47]. Furthermore, mTOR and PTEN pathways are identified. Those are strongly associated with the AKT/PI3P signal transduction circuitry and frequently overexpressed (mTOR) or inactivated (PTEN) in a variety of cancer, including breast cancer [48, 49].

The presence of immune inflammatory cells at tumor sites is now a hallmark of cancer development [35]. The enhanced macrophage activity may refer to an increased clearance of apoptotic/necrotic cells or celldebris but could also mean increased number of tumorassociated macrophages (TAM). These macrophages facilitate angiogenesis and matrix remodeling, and eventually promote tumor growth and metastasis as they have been found to be associated with poor prognosis in several cancer entities [50]. Increased levels of interleukin signaling $(p=7.41 \mathrm{E}-03)$ and leukocyte extravasation $(p=3.98 \mathrm{E}-03)$ from our dataset (Supplementary Table 2A) are also an indication of inflammatory situations; however, it is difficult to make conclusions how the tumor antagonizing or tumor promoting events take place.

One of the highly represented (75 entries) pathway involves LKB1 mediated signaling $(p=0,0021$, Figure 1B). Concerning the function in epithelial polarity LKB1 is involved in the mechanism of contact inhibition since suppression of its expression destabilize epithelial integrity and the cell became susceptible to Myc-induced transformation $[35,51,52]$. Analysis of the molecular association composition identified Ezrin (EZR) as a unique protein within LKB1 pathway (Figure 2B). The actin microfilament-associated EZR is a key regulator of Src activity $[53,54,55]$ and has important function in tumor induced angio-/lymph angiogenesis [56].

Also, CYLD protein was identified both in Beta1integrin mediated interactions and LKB1 mediated signaling in breast cancer samples. Main function of CYLD is to negatively regulate TNFR-mediated activation of NF-kappa-B signaling, and thus modulates inflammation. Additionally, it can affect cell division/ proliferation through signaling pathways, such as Akt, MAPK or Wnt/Beta-Catenin [36]. Loss of CYLD upregulates NFKB signaling and enhance metastasis in breast cancer [37].

Pathway Commons analysis identified the Kitreceptor mediated signaling pathways with the highest significance $(p=9.68 \mathrm{E}-06)$. The $\mathrm{c}-\mathrm{Kit}$ receptor is also a member of receptor tyrosine-kinase family, which upon binding with its ligand stem cell factor (SCF) could regulate apoptosis, proliferation, differentiation, and cell-motility in a variety of blood cells (red blood cell, T-cells, mast-cells). It has also important function in melanin- and gamete- formation, and Cajal-cells function of the gastrointestinal tract $[57,58]$. Moreover, c-Kit over-expression was frequently found in triple negative breast cancer although its precise role in breast cancer development is still uncovered [59].

Yet another signaling cascade that is not discussed so far but also identified by the PathwayCommons test is the Aurora-A pathway (Figure 1B). It has been shown that Aurora-A is necessary for mitotic entry and centrosome separation, and is frequently overexpressed in various

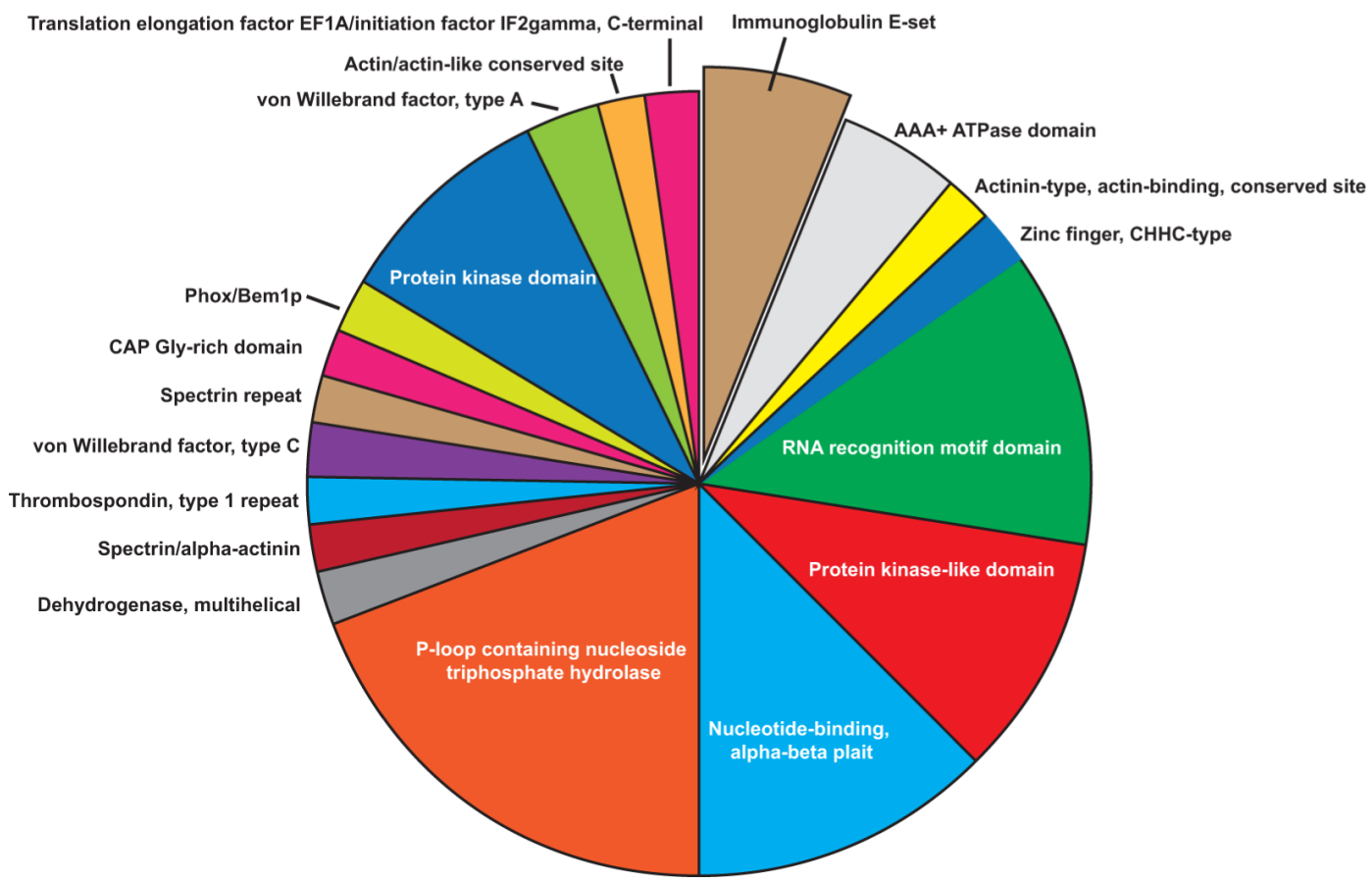

Figure 4: Enriched protein domains $(n=84)$ of the differentially reactive proteins using InterPro database. 


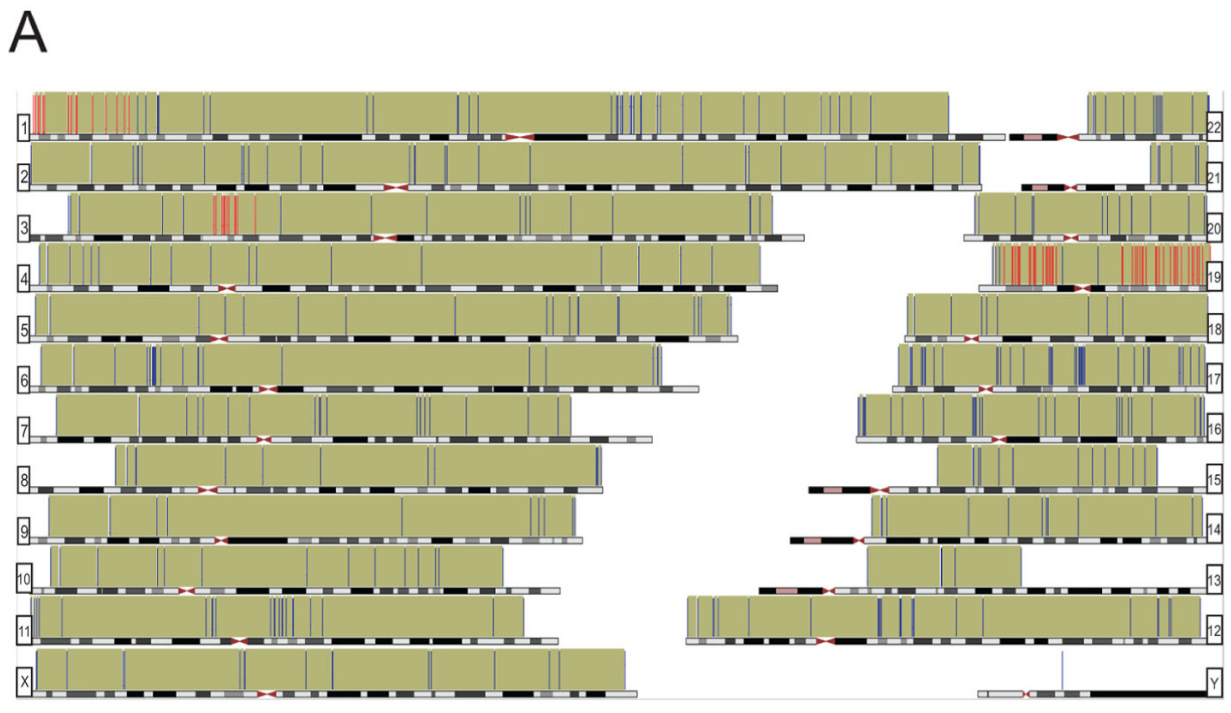

B

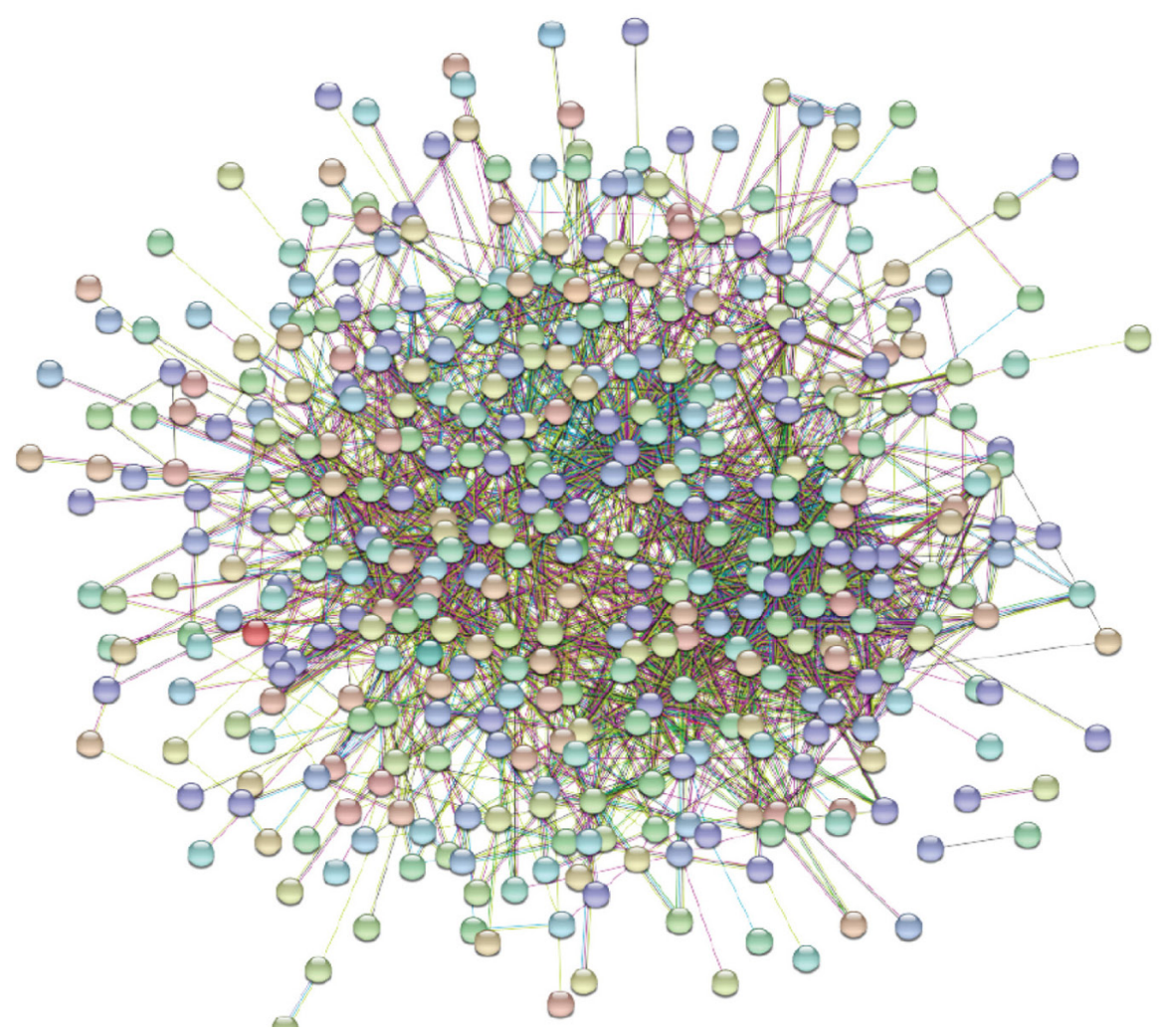

Figure 5: (A) Genomic distribution of the differentially reactive antigens (hg38). Chromosomal locations are represented with bars; red bars indicate enriched regions, according to GSEA database. (B) Deduced protein-protein associations of all mapped $(\mathrm{n}=502)$ differentially reactive proteins, based on String database. Only connected nodes are shown as bubbles. 
cancer types, including breast cancer, but not in benign breast lesions [60]. Mice carrying an MMTV-Aurora-A transgene activate the AKT/mTOR signaling pathways (with high level of CCND1) and are characterized by centrosome amplification, chromosome tetraploidization and premature sister chromatid segregation in the affected cells [61]. In addition to its oncogenic activity, Aurora A has been described as a tumor suppressor as well, which in turn has complicated recent efforts to develop inhibitors against this pleiotropic protein [62].

Taking together the results derived from the comparison of the IgG profile of breast carcinomas and control samples, it was found that those mostly related to the AKT/PI3K/mTOR pathway together with PTEN, complemented with c-Kit and Aurora A-signaling. These are then driving deregulated/changed integrin-, LKB1and VEGF signaling that might lead to impaired celladhesion, contact inhibition and vascularization. The high prevalence of infiltrating immune cells might be indicative of an inflammatory situation during which crosstalk between leukocytes and cancer cells shaping the immune response. Also, the high degree of predicted protein-protein interactions shows the complexity of the underlying molecular pathways and the interconnection of signaling circuits.

\section{MATERIALS AND METHODS}

\section{Clinical/Study samples}

Samples were stored at $-80^{\circ} \mathrm{C}$ until further utilization on protein microarray.

A total of 139 blood samples were collected, 77 of which were collected from patients with breast cancer: invasive ductal carcinoma $(n=53)$, invasive lobular carcinoma $(n=7)$, non-invasive intraductal carcinoma $(n=14)$ and unknown type $(n=3)$. Sixty-two blood samples were collected from healthy volunteers with no individual or familial history of breast or ovarian cancer. Detailed clinical data can be found as Supplementary Table 4.

\section{6k protein microarray generation and processing}

The in-house printed $16 \mathrm{k}$ protein microarray comprised of 6369 distinct proteins from which 5449 have been annotated with a gene-symbol. The recombinant proteins (each represented by 2 to 3 clones) derived from the UniPex expression libraries (human fetal brain, T-cell, lung- and colon expression libraries), developed at the former RZPD (Deutsche Ressourcenzentrum für Genomforschung), Berlin. Detailed description of the $16 \mathrm{~K}$ protein microarray generation can be found in earlier report $[63,64,65]$.

The protein array platform, the technical procedures for sample- and array processing and the application and advantages of purified IgG over raw serum or plasma samples were described previously $[63,66,67]$. Briefly, IgG purification of all serum samples was performed according to the manufacturer's instructions using the Melon $^{\mathrm{TM}}$ Gel IgG Purification Spin Plate Kit (Thermo Scientific, Waltham, MA, USA). Quantifications of IgG samples were performed using the Epoch Microplate Spectrophotometer (BioTek Instruments, Winooski, VT, USA) to ensure their application on the microarrays at the same concentration $(0.3 \mathrm{mg} / \mathrm{mL})$. Integrity of the $\mathrm{IgG}$ samples were checked using SDS-PAGE on pre-casted NuPAGE ${ }^{\circledR}$ Novex 4-12\% Bis-Tris gels (Life Technologies, Carlsbad, CA, USA).

Protein microarray slides were blocked with DIG Easy Hyb solution (Roche, Basel, Swiss). Purified IgG was diluted to $0.3 \mathrm{mg} / \mathrm{mL}$ in two steps: first Melon ${ }^{\mathrm{TM}} \mathrm{Gel}$ Purification Buffer (Thermo Scientific) to normalized concentration of $0.6 \mathrm{mg} / \mathrm{mL}$ IgG and then $1: 1$ with $2 x$ PBS with $0.2 \%$ Triton $\mathrm{X}-100$ and $6 \%$ milk powder. The arrays were incubated for $4 \mathrm{~h}$ with constant rotation $(12 \mathrm{rpm})$ at room temperature in a microarray hybridization oven (Agilent). After hybridization the slides were washed three times with PBSTx for $5 \mathrm{~min}$, then incubated for $1 \mathrm{~h}$ with Alexa Fluor ${ }^{\circledR} 647$ goat anti-human IgG detection antibody (Invitrogen, Life Technologies). Slides were scanned using $10 \mu \mathrm{m}$ resolution and 70\% PMT to acquire array images.

\section{Data acquisition and statistical analyses}

The scanned array images were imported into the GenePix Pro Microarray Acquisition \& Analysis Software 6.0 (Molecular Devices, Sunnyvale, CA, USA) and the resulting fluorescence intensities of all features were calculated. The local background was subtracted from the median values before statistical data analysis, which was performed using R 2.10.0 and BRB-Array Tools 4.2.1 (https://linus.nci.nih.gov/BRB-ArrayTools.html) [68]. The $\log 2$ transformed intensity data were quantile normalized and filtered to exclude those features where less than $20 \%$ of expression data have at least 1.75 -fold change in either direction from the gene's median value (BRB). Additionally, data were filtered for minimum intensity of $256\left(\log _{2}=8\right)$.

Differentially reactive antigens were determined using class comparison analyses (BRB-Array Tools) [68] at the significance thresholds for univariate tests of $\mathrm{p} \leq 0.001$ and minimum fold changes of 1.5 between groups. Each batch was analyzed separately since our previous experiments [64] showed that high variances could exist between batches, which introduce non-biological differences; furthermore, batch-wise normalizations were also omitted since those could distort expression data. Summary table of differentially reactive antigens, Uniprot accession numbers, fold changes, p-values and False Discovery Rates (FDR) are shown in Supplementary Table 1. 
Quantitative trait analysis was executed in BRB Array Tools to test whether patients age was correlated with the expression of differentially reactive antigens. Summary table can be found as Supplementary Table 5 .

Differentially reactive protein names were submitted and analyzed with Ingenuity (https://www. qiagen.com/ingenuity) using Global Canonical Pathways (GCP) tool, which utilize right-tailed Fisher's exact test for p-value calculations. Pathway-commons analyses were implemented in Webgestalt (Web-based Gene-set Analysis Toolkit; http://webgestalt.org) [69, 70, 71], which incorporate various tools different from Ingenuity. Webgestalt uses hypergeometric test for enrichment analyses and for each analysis the top 10 most significant categories were selected (as at least 2 proteins per category). Comparing identified differentially reactive antigens (as gene set) with other publicly available microarray results we used Molecular Signature Database (MSigDB) within GSEA, where oncogenic and immunologic signatures were tested (http://software. broadinstitute.org/gsea/index.jsp) [72, 73]. Cytogenetic mapping (enrichment) analysis was also performed in GSEA, then UCSC table browser and Genome graph tools were used to illustrate genomic locations.

For KEGG (Kyoto Encyclopedia of Genes and Genomes), Reactome, Interpro protein domain-based functional classification and protein-protein interactions analysis and visualization we have utilized String (Search Tool for the Retrieval of Interacting Genes/Proteins; https://string-db.org/) protein interaction database or through Reactome website (https://reactome.org) [74, 75, $76,77]$.

In each analysis, as background proteins (i.e. random entries), we have used all annotated proteins presented on the $16 \mathrm{k}$ protein microarray; except for cytogenetic map analyses (GSEA) where the whole human genome (as gene-positions) was applied (Genome Reference Consortium Human Build 38).

\section{CONCLUSIONS}

Detecting tumor-associated antibodies represents a highly attractive way for early diagnostics of cancer entities. Earlier discovery studies explain the underlying biological phenomenon as the immune response against mutated or aberrantly expressed proteins, which results in elevated reactivity. We think that, on one hand, the majority of identified antigens derive from the clearance of necrotic cells, which upon dying release large number of "targets" for the immune system, regardless if mutated or not. These events are complemented with the degradation of extracellular matrix, which not only emit ECM (Extracellular Matrix) constituents into the tumor microenvironment /circulation, but triggers sequestered growth factors. On the other hand, the observed reduced reactivity can be explained by the immune suppressive environment, orchestrated by the tumor cells. Despite the above potential explanations, due to high complexities of molecular interactions, it is difficult to figure out why reactivity of certain proteins was increased or decreased in cancer samples. Nevertheless, findings from our study reflect that the underlying signaling pathways are highly comparable to and complementing the information derived from gene expression profiling experiments of tumor tissue samples. In conclusion, inferring molecular pathways from antibody profiling provides a new molecular pathological layer of information associated with the health status of patients. Besides, the identified differentially antigens can be further analyzed as potential biomarkers in diagnostic tests or as immune therapy targets.

\section{Author contributions}

$\mathrm{SH}$, JL and IG performed and analyzed the microarray experiments; IG interpreted data and wrote the manuscript; CS and DM coordinated patient recruitment and clinical examination of patients; AW designed, coordinated, interpreted, supervised the study and corrected the manuscript.

\section{ACKNOWLEDGMENTS}

We want to thank Ronald Kulovics and Michael Stierschneider (AIT) for protein purification and array printing, and Yen Y. Tan (MedUniWien) for critical reading of the manuscript.

\section{Ethics statement}

The study was approved by the Ethics Committee of the Medical University of Vienna (EK number 143/2007) and the General Hospital of Vienna and was performed in compliance with the Helsinki Declaration. Informed consent was obtained from the participants prior to blood sample collection.

\section{CONFLICTS OF INTEREST}

The authors declare no conflicts of interest.

\section{REFERENCES}

1. Golubnitschaja O, Debald M, Yeghiazaryan K, Kuhn W, Pešta M, Costigliola V, Grech G. Breast cancer epidemic in the early twenty-first century: evaluation of risk factors, cumulative questionnaires and recommendations for preventive measures. Tumour Biol. 2016; 37:12941-57. https://doi.org/10.1007/s13277-016-5168-x. [PubMed]

2. Ferlay J, Soerjomataram I, Ervik M, Dikshit R, Eser S, Mathers C, Rebelo M, Parkin DM, Forman D, Bray F. GLOBOCAN 2012 v1.0, Cancer Incidence and Mortality Worldwide: IARC CancerBase No. 11. Lyon, France: 
International Agency for Research on Cancer; 2013. Available from: http://globocan.iarc.fr.

3. Trivers GE, De Benedetti VM, Cawley HL, Caron G, Harrington AM, Bennett WP, Jett JR, Colby TV, Tazelaar H, Pairolero P, Miller RD, Harris CC. Anti-p53 antibodies in sera from patients with chronic obstructive pulmonary disease can predate a diagnosis of cancer. Clin Cancer Res. 1996; 2:1767-75. [PubMed]

4. Foley EJ. Antigenic properties of methylcholanthreneinduced tumors in mice of the strain of origin. Cancer Res. 1953; 13:835-37. [PubMed]

5. Finnigan JP Jr, Rubinsteyn A, Hammerbacher J, Bhardwaj N. Mutation-Derived Tumor Antigens: Novel Targets in Cancer Immunotherapy. Oncology (Williston Park). 2015; 29:970-72, 974-75. [PubMed]

6. Coulie PG, Van den Eynde BJ, van der Bruggen P, Boon T. Tumour antigens recognized by $\mathrm{T}$ lymphocytes: at the core of cancer immunotherapy. Nat Rev Cancer. 2014; 14:13546. https://doi.org/10.1038/nrc3670. [PubMed]

7. Luna Coronell JA, Syed $\mathrm{P}$, Sergelen K, Gyurján I, Weinhäusel A. The current status of cancer biomarker research using tumour-associated antigens for minimal invasive and early cancer diagnostics. J Proteomics. 2012; 76:102-15. $\quad$ https://doi.org/10.1016/j.jprot.2012.07.022. [PubMed]

8. Kobold S, Lütkens T, Cao Y, Bokemeyer C, Atanackovic D. Autoantibodies against tumor-related antigens: incidence and biologic significance. Hum Immunol. 2010; 71:643-51. https://doi.org/10.1016/j.humimm.2010.03.015. [PubMed]

9. Reuschenbach M, von Knebel Doeberitz M, Wentzensen N. A systematic review of humoral immune responses against tumor antigens. Cancer Immunol Immunother. 2009; 58:1535-44. https://doi.org/10.1007/s00262-009-0733-4. [PubMed]

10. Tan EM. Autoantibodies as reporters identifying aberrant cellular mechanisms in tumorigenesis. J Clin Invest. 2001; 108:1411-15. https://doi.org/10.1172/JCI14451. [PubMed]

11. Anderson KS, LaBaer J. The sentinel within: exploiting the immune system for cancer biomarkers. J Proteome Res. 2005; 4:1123-33. https://doi.org/10.1021/pr0500814. [PubMed]

12. Backes C, Ludwig N, Leidinger P, Harz C, Hoffmann J, Keller A, Meese E, Lenhof HP. Immunogenicity of autoantigens. BMC Genomics. 2011; 12:340. https://doi.org/10.1186/1471-2164-12-340. [PubMed]

13. Poon IK, Lucas CD, Rossi AG, Ravichandran KS. Apoptotic cell clearance: basic biology and therapeutic potential. Nat Rev Immunol. 2014; 14:166-80. https://doi.org/10.1038/nri3607. [PubMed]

14. Huang J, Xie Y, Sun X, Zeh HJ 3rd, Kang R, Lotze MT, Tang D. DAMPs, ageing, and cancer: The 'DAMP Hypothesis'. Ageing Res Rev. 2015; 24:3-16. https://doi.org/10.1016/j.arr.2014.10.004. [PubMed]
15. Vakkila J, Lotze MT. Inflammation and necrosis promote tumour growth. Nat Rev Immunol. 2004; 4:641-48. https://doi.org/10.1038/nri1415. [PubMed]

16. Kaigorodova EV, Bogatyuk MV. Heat shock proteins as prognostic markers of cancer. Curr Cancer Drug Targets. 2014; 14:713-26. https://doi.org/10.2174/1568009614666140926122846. [PubMed]

17. Bhatelia K, Singh K, Singh R. TLRs: linking inflammation and breast cancer. Cell Signal. 2014; 26:2350-57. https://doi.org/10.1016/j.cellsig.2014.07.035. [PubMed]

18. Kang R, Zhang Q, Zeh HJ 3rd, Lotze MT, Tang D. HMGB1 in cancer: good, bad, or both? Clin Cancer Res. 2013; 19:4046-57. https://doi.org/10.1158/1078-0432.CCR-13-0495. [PubMed]

19. Bertos NR, Park M. Breast cancer - one term, many entities? J Clin Invest. 2011; 121:3789-96. https://doi.org/10.1172/ $\underline{\mathrm{JCI} 57100}$. [PubMed]

20. Noto H, Tsujimoto T, Sasazuki T, Noda M. Significantly increased risk of cancer in patients with diabetes mellitus: a systematic review and meta-analysis. Endocr Pract. 2011; 17:616-28. https://doi.org/10.4158/EP10357.RA. [PubMed]

21. Lipscombe LL, Fischer HD, Austin PC, Fu L, Jaakkimainen RL, Ginsburg O, Rochon PA, Narod S, Paszat L. The association between diabetes and breast cancer stage at diagnosis: a population-based study. Breast Cancer Res Treat. 2015; 150:613-20. https://doi.org/10.1007/s10549-015-3323-5. [PubMed]

22. Guilliams M, Bruhns P, Saeys Y, Hammad H, Lambrecht $\mathrm{BN}$. The function of Fc $\gamma$ receptors in dendritic cells and macrophages. Nat Rev Immunol. 2014; 14:94-108. https://doi.org/10.1038/nri3582. Erratum in: Nat Rev Immunol. 2014 May;14(5):349. [PubMed]

23. Miller TW, Rexer BN, Garrett JT, Arteaga CL. Mutations in the phosphatidylinositol 3-kinase pathway: role in tumor progression and therapeutic implications in breast cancer. Breast Cancer Res. 2011; 13:224. https://doi.org/10.1186/bcr3039. [ [PubMed]

24. Leach DR, Krummel MF, Allison JP. Enhancement of antitumor immunity by CTLA-4 blockade. Science. 1996; 271:1734-36. https://doi.org/10.1126/science.271.5256.1734. [PubMed]

25. Raymond K, Cagnet S, Kreft M, Janssen H, Sonnenberg A, Glukhova MA. Control of mammary myoepithelial cell contractile function by $\alpha 3 \beta 1$ integrin signalling. EMBO J. 2011; 30:1896-906. https://doi.org/10.1038/emboj.2011.113. [PubMed]

26. Akhtar N, Streuli CH. An integrin-ILK-microtubule network orients cell polarity and lumen formation in glandular epithelium. Nat Cell Biol. 2013; 15:17-27. https://doi.org/10.1038/ncb2646. [PubMed]

27. Ramirez NE, Zhang Z, Madamanchi A, Boyd KL, O'Rear LD, Nashabi A, Li Z, Dupont WD, Zijlstra A, Zutter MM. The $\alpha 2 \beta 1$ integrin is a metastasis suppressor in mouse 
models and human cancer. J Clin Invest. 2011; 121:226-37. https://doi.org/10.1172/JCI42328. [PubMed]

28. Guo W, Pylayeva Y, Pepe A, Yoshioka T, Muller WJ, Inghirami G, Giancotti FG. Beta 4 integrin amplifies ErbB2 signaling to promote mammary tumorigenesis. Cell. 2006; 126:489-502. https://doi.org/10.1016/j.cell.2006.05.047. [PubMed]

29. Glukhova MA, Streuli CH. How integrins control breast biology. Curr Opin Cell Biol. 2013; 25:633-41. https://doi.org/10.1016/j.ceb.2013.06.010. [PubMed]

30. Goldman FD, Ballas ZK, Schutte BC, Kemp J, Hollenback C, Noraz N, Taylor N. Defective expression of p56lck in an infant with severe combined immunodeficiency. J Clin Invest. 1998; 102:421-29. https://doi.org/10.1172/JCI3205. [PubMed]

31. Korsse SE, Peppelenbosch MP, van Veelen W. Targeting LKB1 signaling in cancer. Biochim Biophys Acta. 2013; 1835:194 210. https://doi.org/10.1016/j.bbcan.2012.12.006. [PubMed]

32. Shaw RJ. Tumor suppression by LKB1: SIKness prevents metastasis. Sci Signal. 2009; 2:pe55. https://doi.org/10.1126/scisignal.286pe55. [PubMed]

33. Forster LF, Defres S, Goudie DR, Baty DU, Carey FA. An investigation of the Peutz-Jeghers gene (LKB1) in sporadic breast and colon cancers. J Clin Pathol. 2000; 53:791-3. https://doi.org/10.1136/jep.53.10.791. [PubMed]

34. Gan RY, Li HB. Recent progress on liver kinase B1 (LKB1): expression, regulation, downstream signaling and cancer suppressive function. Int J Mol Sci. 2014; 15:16698718. https://doi.org/10.3390/ijms150916698. [PubMed]

35. Hanahan D, Weinberg RA. Hallmarks of cancer: the next generation. Cell. 2011; 144:646-74. https://doi.org/10.1016/j.cell.2011.02.013. [PubMed]

36. Mathis BJ, Lai Y, Qu C, Janicki JS, Cui T. CYLD-mediated signaling and diseases. Curr Drug Targets. 2015; 16:28494. https://doi.org/10.2174/1389450115666141024152421. [PubMed]

37. Hayashi M, Jono H, Shinriki S, Nakamura T, Guo J, Sueta A, Tomiguchi M, Fujiwara S, Yamamoto-Ibusuki M, Murakami K, Yamashita S, Yamamoto Y, Li JD, et al. Clinical significance of CYLD downregulation in breast cancer. Breast Cancer Res Treat. 2014; 143:447-57. https://doi.org/10.1007/s10549-013-2824-3. [PubMed]

38. Delconte RB, Kolesnik TB, Dagley LF, Rautela J, Shi W, Putz EM, Stannard K, Zhang JG, Teh C, Firth M, Ushiki T, Andoniou CE, Degli-Esposti MA, et al. CIS is a potent checkpoint in NK cell-mediated tumor immunity. Nat Immunol. 2016; 17:816-24. https://doi.org/10.1038/ ni.3470. [PubMed]

39. Bevilacqua A, Ceriani MC, Capaccioli S, Nicolin A. Posttranscriptional regulation of gene expression by degradation of messenger RNAs. J Cell Physiol. 2003; 195:356-72. https://doi.org/10.1002/jep.10272. [PubMed]

40. Bosher JM, Williams T, Hurst HC. The developmentally regulated transcription factor AP-2 is involved in c-erbB-2 overexpression in human mammary carcinoma. Proc Natl Acad Sci U S A. 1995; 92:744-47. https://doi.org/10.1073/pnas.92.3.744. [PubMed]

41. Cyr AR, Kulak MV, Park JM, Bogachek MV, Spanheimer PM, Woodfield GW, White-Baer LS, O’Malley YQ, Sugg SL, Olivier AK, Zhang W, Domann FE, Weigel RJ. TFAP2C governs the luminal epithelial phenotype in mammary development and carcinogenesis. Oncogene. 2015; 34:43644. https://doi.org/10.1038/onc.2013.569. [PubMed]

42. Manning G, Plowman GD, Hunter T, Sudarsanam S. Evolution of protein kinase signaling from yeast to man. Trends Biochem Sci. 2002; 27:514-20. https://doi. org/10.1016/S0968-0004(02)02179-5. [PubMed]

43. Dunn GP, Bruce AT, Ikeda H, Old LJ, Schreiber RD. Cancer immunoediting: from immunosurveillance to tumor escape. Nat Immunol. 2002; 3:991-98. https://doi.org/10.1038/ ni1102-991. [PubMed]

44. Hodi FS, O’Day SJ, McDermott DF, Weber RW, Sosman JA, Haanen JB, Gonzalez R, Robert C, Schadendorf D, Hassel JC, Akerley W, van den Eertwegh AJ, Lutzky J, et al. Improved survival with ipilimumab in patients with metastatic melanoma. N Engl J Med. 2010; 363:711-23. https://doi.org/10.1056/NEJMoa1003466. [ [PubMed]

45. Huang CT, Workman CJ, Flies D, Pan X, Marson AL, Zhou G, Hipkiss EL, Ravi S, Kowalski J, Levitsky HI, Powell JD, Pardoll DM, Drake CG, Vignali DA. Role of LAG-3 in regulatory T cells. Immunity. 2004; 21:503-13. https://doi.org/10.1016/j.immuni.2004.08.010. [PubMed]

46. Wurz GT, Kao CJ, DeGregorio MW. Novel cancer antigens for personalized immunotherapies: latest evidence and clinical potential. Ther Adv Med Oncol. 2016; 8:4-31. https://doi.org/10.1177/1758834015615514. [PubMed]

47. Kessenbrock K, Plaks V, Werb Z. Matrix metalloproteinases: regulators of the tumor microenvironment. Cell. 2010; 141:52-67. https://doi.org/10.1016/j.cell.2010.03.015. [PubMed]

48. Zhou X, Tan M, Stone Hawthorne V, Klos KS, Lan KH, Yang Y, Yang W, Smith TL, Shi D, Yu D. Activation of the Akt/mammalian target of rapamycin/4E-BP1 pathway by ErbB2 overexpression predicts tumor progression in breast cancers. Clin Cancer Res. 2004; 10:6779-88. https://doi.org/10.1158/1078-0432.CCR-04-0112. [PubMed]

49. Davis NM, Sokolosky M, Stadelman K, Abrams SL, Libra M, Candido S, Nicoletti F, Polesel J, Maestro R, D'Assoro A, Drobot L, Rakus D, Gizak A, et al. Deregulation of the EGFR/PI3K/PTEN/Akt/mTORC1 pathway in breast cancer: possibilities for therapeutic intervention. Oncotarget. 2014; 5:4603-50. $\quad$ https://doi.org/10.18632/oncotarget.2209. [PubMed]

50. Mantovani A, Schioppa T, Porta C, Allavena P, Sica A. Role of tumor-associated macrophages in tumor progression and invasion. Cancer Metastasis Rev. 2006; 25:315-22. https://doi.org/10.1007/s10555-006-9001-7. [PubMed] 
51. Partanen JI, Nieminen AI, Klefstrom J. 3D view to tumor suppression: Lkb1, polarity and the arrest of oncogenic c-Myc. Cell Cycle. 2009; 8:716-24. https://doi.org/10.4161/cc.8.5.7786. [PubMed]

52. Hezel AF, Bardeesy N. LKB1; linking cell structure and tumor suppression. Oncogene. 2008; 27:6908-19. https://doi.org/10.1038/onc.2008.342. [PubMed]

53. Sarrió D, Rodríguez-Pinilla SM, Dotor A, Calero F, Hardisson D, Palacios J. Abnormal ezrin localization is associated with clinicopathological features in invasive breast carcinomas. Breast Cancer Res Treat. 2006; 98:7179. https://doi.org/10.1007/s10549-005-9133-4. [PubMed]

54. Elliott BE, Qiao H, Louvard D, Arpin M. Co-operative effect of $\mathrm{c}$-Src and ezrin in deregulation of cell-cell contacts and scattering of mammary carcinoma cells. J Cell Biochem. 2004; 92:16-28. https://doi.org/10.1002/jcb.20033. [PubMed]

55. Elliott BE, Meens JA, SenGupta SK, Louvard D, Arpin M. The membrane cytoskeletal crosslinker ezrin is required for metastasis of breast carcinoma cells. Breast Cancer Res. 2005; 7:R365-73. https://doi.org/10.1186/bcr1006. [PubMed]

56. Ghaffari A, Hoskin V, Szeto A, Hum M, Liaghati N, Nakatsu K, LeBrun D, Madarnas Y, Sengupta S, Elliott BE. A novel role for ezrin in breast cancer angio/ lymphangiogenesis. Breast Cancer Res. 2014; 16:438. https://doi.org/10.1186/s13058-014-0438-2. Erratum in: Erratum to: "A novel role for ezrin in breast cancer angio/ lymphangiogenesis". [Breast Cancer Res. 2015]. [PubMed]

57. Liang J, Wu YL, Chen BJ, Zhang W, Tanaka Y, Sugiyama $\mathrm{H}$. The C-kit receptor-mediated signal transduction and tumor-related diseases. Int J Biol Sci. 2013; 9:435-43. https://doi.org/10.7150/ijbs.6087. [PubMed]

58. Huizinga JD, Thuneberg L, Klüppel M, Malysz J, Mikkelsen $\mathrm{HB}$, Bernstein A. W/kit gene required for interstitial cells of Cajal and for intestinal pacemaker activity. Nature. 1995; 373:347-49. https://doi.org/10.1038/373347a0. [PubMed]

59. Jansson S, Bendahl PO, Grabau DA, Falck AK, Fernö M, Aaltonen K, Rydén L. The three receptor tyrosine kinases c-KIT, VEGFR2 and PDGFR $\alpha$, closely spaced at $4 \mathrm{q} 12$, show increased protein expression in triplenegative breast cancer. PLoS One. 2014; 9:e102176. https://doi.org/10.1371/journal.pone.0102176. [PubMed]

60. Tanaka T, Kimura M, Matsunaga K, Fukada D, Mori H, Okano Y. Centrosomal kinase AIK1 is overexpressed in invasive ductal carcinoma of the breast. Cancer Res. 1999; 59:2041-44. [PubMed]

61. Wang X, Zhou YX, Qiao W, Tominaga Y, Ouchi M, Ouchi T, Deng CX. Overexpression of aurora kinase A in mouse mammary epithelium induces genetic instability preceding mammary tumor formation. Oncogene. 2006; 25:7148-58. https://doi.org/10.1038/sj.onc.1209707. [PubMed]

62. Damodaran AP, Vaufrey L, Gavard O, Prigent C. Aurora A Kinase Is a Priority Pharmaceutical Target for the Treatment of Cancers. Trends Pharmacol Sci. 2017; 38:687-700. https://doi.org/10.1016/j.tips.2017.05.003. [PubMed]

63. Stempfer R, Syed P, Vierlinger K, Pichler R, Meese E, Leidinger $P$, Ludwig N, Kriegner A, Nöhammer C, Weinhäusel A. Tumour auto-antibody screening: performance of protein microarrays using SEREX derived antigens. BMC Cancer. 2010; 10:627. https://doi.org/10.1186/1471-2407-10-627. [PubMed]

64. Brezina S, Soldo R, Kreuzhuber R, Hofer P, Gsur A, Weinhaeusel A. Immune-Signatures for Lung Cancer Diagnostics: Evaluation of Protein Microarray Data Normalization Strategies. Microarrays (Basel). 2015; 4:162-87. https://doi.org/10.3390/microarrays4020162. [PubMed]

65. Luna-Coronell JA, Vierlinger K, Gamperl M, Hofbauer J, Berger I, Weinhäusel A. The prostate cancer immunome: in silico functional analysis of antigenic proteins from microarray profiling with IgG. Proteomics. 2016; 16:120414. https://doi.org/10.1002/pmic.201500378. [PubMed]

66. Rosskopf S, Gyurján I, Soldo R, Luna-Coronell JA, Vierlinger K, Singer CF, Rappaport C, Pecha N, Weinhaeusel A. The pre-analytical processing of blood samples for detecting biomarkers on protein microarrays. J Immunol Methods. 2015; 418:39-51. https://doi.org/10.1016/j.jim.2015.01.009. Erratum in: J Immunol Methods. 2015 Apr;419:57. Soldo, Regina [Added]. [PubMed]

67. Preininger C, Bodrossy L, Sauer U, Pichler R, Weilharter A. ARChip epoxy and ARChip UV for covalent on-chip immobilization of pmoA gene-specific oligonucleotides. Anal Biochem. 2004; 330:29-36. https://doi.org/10.1016/j.ab.2003.12.037. [PubMed]

68. Simon R, Lam A, Li MC, Ngan M, Menenzes S, Zhao Y. Analysis of gene expression data using BRB-ArrayTools. Cancer Inform. 2007; 3:11-7. https://doi.org/10.1177/117693510700300022. [PubMed]

69. Cerami EG, Gross BE, Demir E, Rodchenkov I, Babur O, Anwar N, Schultz N, Bader GD, Sander C. Pathway Commons, a web resource for biological pathway data. Nucleic Acids Res. 2011; 39:D685-90. https://doi.org/10.1093/nar/gkq1039. [PubMed]

70. Zhang B, Kirov S, Snoddy J. WebGestalt: an integrated system for exploring gene sets in various biological contexts. Nucleic Acids Res. 2005; 33:W741-8. https://doi.org/10.1093/nar/gki475. [PubMed]

71. Wang J, Duncan D, Shi Z, Zhang B. WEB-based GEne SeT AnaLysis Toolkit (WebGestalt): update 2013. Nucleic Acids Res. 2013; 41:W77-83. https://doi.org/10.1093/nar/gkt439. [PubMed]

72. Mootha VK, Lindgren CM, Eriksson KF, Subramanian A, Sihag S, Lehar J, Puigserver P, Carlsson E, Ridderstråle M, Laurila E, Houstis N, Daly MJ, Patterson N, et al. PGC-1alpha-responsive genes involved in oxidative phosphorylation are coordinately downregulated 
in human diabetes. Nat Genet. 2003; 34:267-73. https://doi.org/10.1038/ng1180. [PubMed]

73. Subramanian A, Tamayo P, Mootha VK, Mukherjee S, Ebert BL, Gillette MA, Paulovich A, Pomeroy SL, Golub TR, Lander ES, Mesirov JP. Gene set enrichment analysis: a knowledge-based approach for interpreting genomewide expression profiles. Proc Natl Acad Sci U S A. 2005; 102:15545-50. https://doi.org/10.1073/pnas.0506580102. [PubMed]

74. Kanehisa M, Goto S. KEGG: kyoto encyclopedia of genes and genomes. Nucleic Acids Res. 2000; 28:27-30. https://doi.org/10.1093/nar/28.1.27. [PubMed]

75. Croft D, O'Kelly G, Wu G, Haw R, Gillespie M, Matthews L, Caudy M, Garapati P, Gopinath G, Jassal B, Jupe S, Kalatskaya I, Mahajan S, et al. Reactome: a database of reactions, pathways and biological processes. Nucleic Acids Res. 2011; 39:D691-97. https://doi.org/10.1093/nar/gkq1018. [PubMed]

76. Snel B, Lehmann G, Bork P, Huynen MA. STRING: a web-server to retrieve and display the repeatedly occurring neighbourhood of a gene. Nucleic Acids Res. 2000; 28:3442-44. https://doi.org/10.1093/nar/28.18.3442. [PubMed]

77. Fabregat A, Sidiropoulos K, Garapati P, Gillespie M, Hausmann K, Haw R, Jassal B, Jupe S, Korninger F, McKay S, Matthews L, May B, Milacic M, et al. The Reactome pathway Knowledgebase. Nucleic Acids Res. 2016; 44:D481-87. https://doi.org/10.1093/nar/gkv1351. [PubMed] 